\title{
Conservation implications of the temporal and spatial distribution of Bearded Vulture Gypaetus barbatus in Crete
}

\author{
STAVROS XIROUCHAKIS and MANOLIS NIKOLAKAKIS
}

\begin{abstract}
Summary
We carried out a four-year (1995-1999) survey on the foraging and breeding distribution of Bearded Vulture Gypaetus barbatus on the island of Crete. The age classes of all birds sighted were systematically recorded and data on seasonal distribution patterns were collected; 262 observations were made covering an area of about 4,000 $\mathrm{km}^{2}$, at altitudes ranging from $200 \mathrm{~m}$ to $2,450 \mathrm{~m}$ a.s.l (mean 1,100 $\mathrm{m}$ ). Adult birds were distributed evenly throughout the island while young birds avoided active territories and were mostly sighted at the periphery of the high mountains. The species depended almost entirely on domestic livestock herded into and away from the mountains seasonally, with birds foraging in the uplands (> 1,200 m a.s.l.) from early May to late October and frequenting midland pastures (600-1,200 $\mathrm{m}$ a.s.1.) for the rest of the year. The mean altitude of nesting sites was $750 \mathrm{~m}$ (range $=280-1,450 \mathrm{~m}$ ), with $80 \%$ of nests positioned below the $1,000 \mathrm{~m}$ contour. Bearded Vultures are more vulnerable to human-induced mortality within their breeding territories and on midland pastures in winter than in the upland areas in summer.
\end{abstract}

\section{Introduction}

Bearded Vulture Gypaetus barbatus is a solitary cliff-nesting raptor inhabiting mountain regions of Eurasia and Africa (Cramp and Simmons 1980). It feeds on carrion ranging in size from small rodents and birds to large ungulates (Hiraldo et al. 1979, Brown 1991, Heredia and Heredia 1991). The distribution and density of this species is often correlated with domestic livestock management practices (Suetens and Van Groendeael 1973, Brown 1977, Brown and Plug 1990, Heredia and Heredia 1991, Thibault et al. 1992) and it is regarded as commensal with man (Brown 1977). Nests are built in small caves or on rock ledges on high, inaccessible cliffs typically between 1,000 and 3,000 $\mathrm{m}$ a.s.1., usually away from human settlements (Cramp and Simmons 1980, Donázar et al. 1993). Its European population numbers about 120 breeding pairs, having suffered a severe decline during the nineteenth and twentieth centuries (Tucker and Heath 1994, R. Heredia pers. comm.). In Greece, Bearded Vulture is the most endangered vertebrate, with the island of Crete hosting four breeding pairs and an estimated 28 individuals, constituting the last breeding population in the whole Balkan region (Xirouchakis et al. 2001). Domestic ungulates, which number more than a million (National Statistical Service 1991) are the main food source for the vultures, but 
although livestock distribution is almost even in space, it varies seasonally. Large flocks, up to 750,000 animals in total (Katsavelis et al. 1993), are set loose or transferred to their summer pastures in the uplands from late April until mid November, and remain in mid and low altitude areas for the rest of the year.

The purpose of this paper is to: (a) determine the distribution of Bearded Vulture on the island; (b) identify foraging and breeding ranges; and (c) elucidate conservation problems related to its seasonal distribution patterns.

\section{Study area}

Crete, in the South Aegean Sea, is the largest Greek island covering an area of $8,261 \mathrm{~km}^{2}$. It stretches over $256 \mathrm{~km}$ from east to west and on average c. $40 \mathrm{~km}$ from north to south (range $=11-56 \mathrm{~km} ; 35^{\circ} 45^{\prime}$ to $34^{\circ} 45^{\prime} \mathrm{N}, 23^{\circ} 30^{\prime}$ to $26^{\circ} 30^{\prime} \mathrm{E}$ ). Three major massifs occur, Lefka Oroi (highest point 2,450 m), Oros Psiloritis (highest point 2,457 m) and Oros Dikti (highest point 2,100 m). The general topography of the island also comprises a few plains and many hills covered with extensive vineyards and olive groves. Annual precipitation ranges from $400 \mathrm{~mm}$ to $2,000 \mathrm{~mm}$, mean winter temperature from $4{ }^{\circ} \mathrm{C}$ to $12{ }^{\circ} \mathrm{C}$ and summer temperature from $17{ }^{\circ} \mathrm{C}$ to $27{ }^{\circ} \mathrm{C}$, depending on altitude (Penna 1977). Winters are moderate and rather wet, especially in the east and north of the island, while summers are dry and hot. Snow is common on the mountains and may last from late November to late April and exceptionally early June. Natural vegetation has been modified by humans for at least the last 3,000 years and at present is dominated by cushion-type shrubs called phrygana, dry-leafed maquis and sparse forests and patches of Calamprian pine Pinus brutia, Kermes-oak Quercus coccifera, Cypress Cupressus sempervirens and oaks $Q$. pubescens and Q. macrolepis.

\section{Methods}

Sightings of Bearded Vultures were recorded between September 1996 and February 1999 ( 329 days or 2,237 hours) with observation effort equally divided in space and time. Additional incidental observations were made to May 2001. Sightings were made from a vehicle travelling at a mean speed of $35 \mathrm{~km}$ per hour but mostly from vantage points with good views over the sampling areas (Bilstein 1978, Fuller and Mosher 1987) using $10 \times 50$ binoculars and a 30-60 $\times$ spotting scope. The exact location of each sighting and direction of flight was plotted on 1:50,000 topographical maps with $25 \mathrm{~km}^{2}$ grids. Each vulture sighted was allocated to one of four age classes (Forsman 1999): juvenile (o-3.5 years), immature ( $3.5-4$ years), sub-adult ( $4-5$ years) and adult ( $>6$ years), although non-adult individuals were pooled together in the analysis of the data. An intensive effort was made during mid October to late February every year to find Bearded Vulture nests and roosting sites. Apart from direct observations, ornithological reports were searched to locate deserted territories and old nesting cliffs were inspected.

Observations were entered onto a spreadsheet (MS Access version 9.0) recording date, time, altitude, location, $10 \times 10 \mathrm{~km}$ grid code number of the Universal Traverse Mercator (UTM) coordinate system, age class and activity (e.g. roosting, 
flapping, gliding or soaring), plumage pattern, intra- and inter-specific interactions and general comments. The distribution of different age classes was compared using $z$ and $t$ tests. The monthly sighting rate was calculated as Bearded Vulture contacts per observation hour. The chi-square $\left(\chi^{2}\right)$ test was used for the investigation of any association between age and months (that were grouped in pairs) and a two-way Analysis of Variance for any significant differences in sighting rates (Zar 1984). Seasons were divided into winter (15 November-14 April) and summer (15 April-14 November) based on the period of rainfall and duration of snow cover.

Distribution maps were produced using ARC/VIEW 3.2 at a resolution of $1 \times$ $1 \mathrm{~km}$ on a map of Crete scaled at 1:100,000 with $400 \mathrm{~m}$ contour intervals. Observations of a foraging vulture covering a number of different $1 \times 1 \mathrm{~km}$ grid cells were considered as different records. Sightings of birds gliding at high speed between distant mountains and at a great height were excluded. Bearded Vulture records from unpublished accounts that covered the majority of the species' territories in the same years and birds seen during regular monitoring undertaken up to May 2001 were also included in the analysis. Since not all Bearded Vulture observations were made in the centre of each $1 \times 1 \mathrm{~km}$ grid, the ARC/VIEW density function was used with cells of $100 \times 100 \mathrm{~m}$ to show the distribution of observations throughout the landscape and create a continuous surface. This function considers where the grid centre is in relation to other grid centres, the quantity of observations at those centres, and how many cells need to share a portion of this quantity. Cells nearer to the grid centres receive higher proportions of the measured quantity (e.g. number of observations) than those further away. Observation values of all the $100 \times 100 \mathrm{~m}$ cells equal the sum of observations in each $1 \times 1 \mathrm{~km}$ grid. The output is an observation density surface where areas of major activity are enhanced (e.g. around breeding and roosting sites). Similarly in the construction of distribution maps by season or age class the inverse distance weighted interpolation method was used with cells of one-mile radius around each observation to show the concentration of observations in different mountain areas. The method assumes that each observation has an influence in all points within the specified radius cells which diminishes with distance. It weights the points closer to the processing cell greater than those farther away.

\section{Results}

A total of 702 Bearded Vulture records were obtained between 1985 and 2001 consisting of 910 individual bird sightings (744 adult and 166 immature). Bearded Vultures were recorded from $200 \mathrm{~m}$ a.s.l. near sea cliffs to $2,450 \mathrm{~m}$ amongst the mountain peaks, covering a theoretical area of about $6,000 \mathrm{~km}^{2}$. However the majority of observations were made above the $400 \mathrm{~m}$ contour, giving a more realistic foraging range of $3,275 \mathrm{~km}^{2}$ in winter (up to the snow line at $1,000 \mathrm{~m}$ ) and $3,896 \mathrm{~km}^{2}$ in summer. Breeding and roosting sites produced the highest density of observations and were mostly located at the periphery of the mountains or near the sea on precipitous cliff faces (Figure 1). All nests found $(n=25)$ were on rocks of limestone substrate and had a nest bowl lined with wool. Their altitude ranged from $280 \mathrm{~m}$ to $1,450 \mathrm{~m}$ 

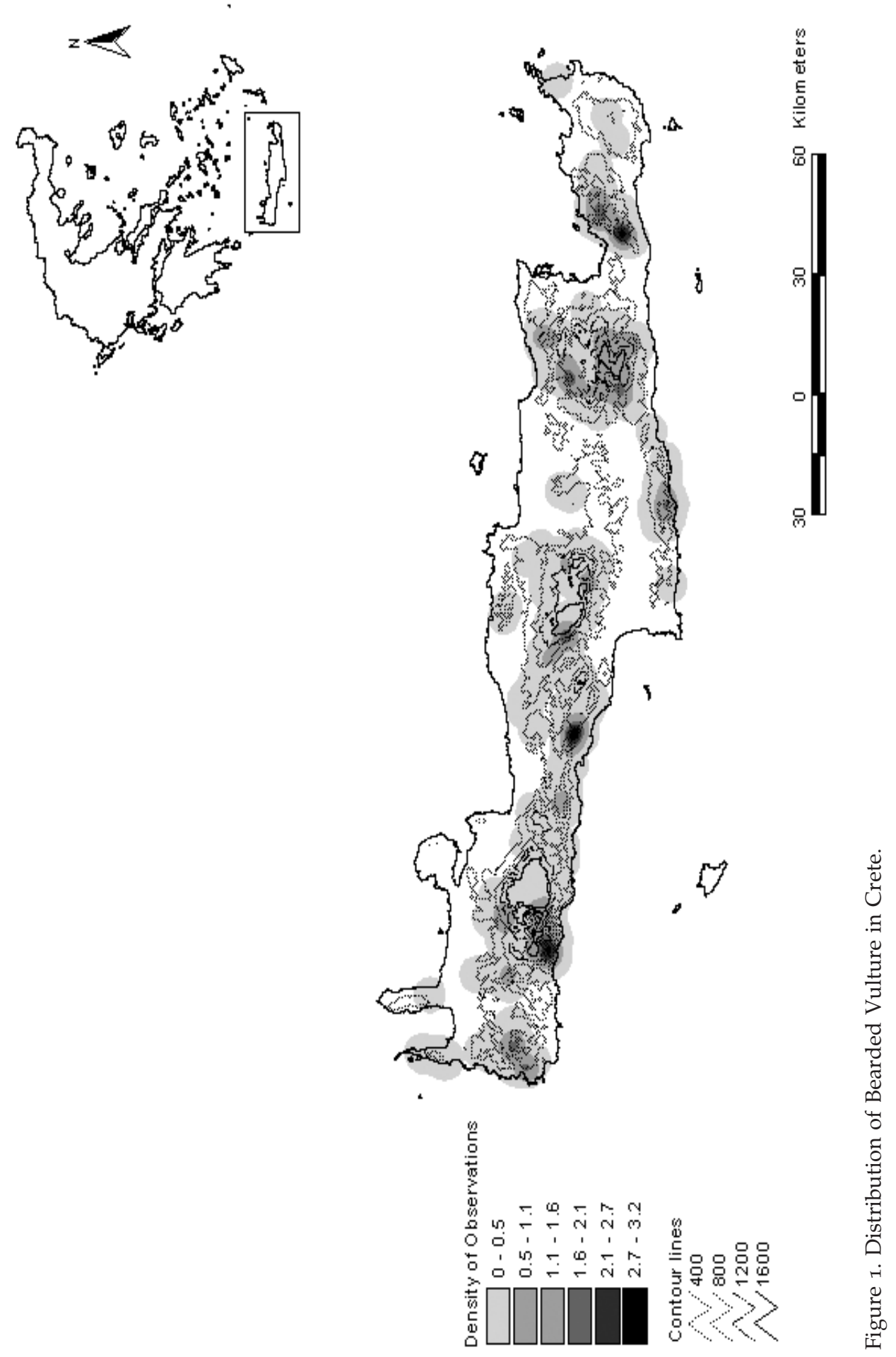


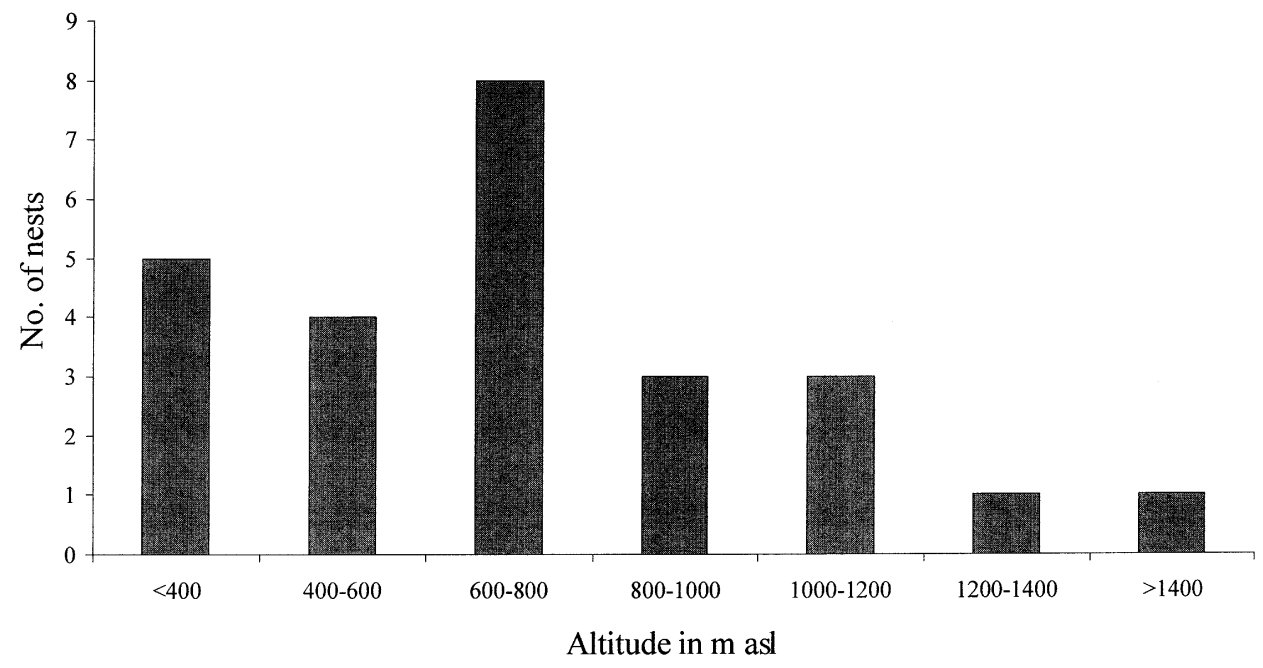

Figure 2. Altitude of Bearded Vulture nests in Crete.

(mean $750 \mathrm{~m}$ ) with $20(80 \%)$ of them below 1,000 m (Figure 2). Nests were built in potholes $(56 \%)$ or on rock ledges with a gentle cliff overhang (44\%). Breeding success of 15 pair-years was $53 \%$ while mean annual productivity during 1996-2001 was 0.34 chicks per pair per year.

The sighting rate of birds was not significantly different in winter than in summer (mean 0.13 and mean 0.11 respectively; $t=0.81, d f=10, P>0.05, n=$ 332). Sightings of adult birds peaked in December while that of immature birds peaked in September to January and decreased thereafter (Figure 3). No association was detected in sighting rates between age classes and between months $\left(\chi^{2}=0.065\right.$, d.f. $\left.=5, P>0.05\right)$ although the sighting rate throughout the year was

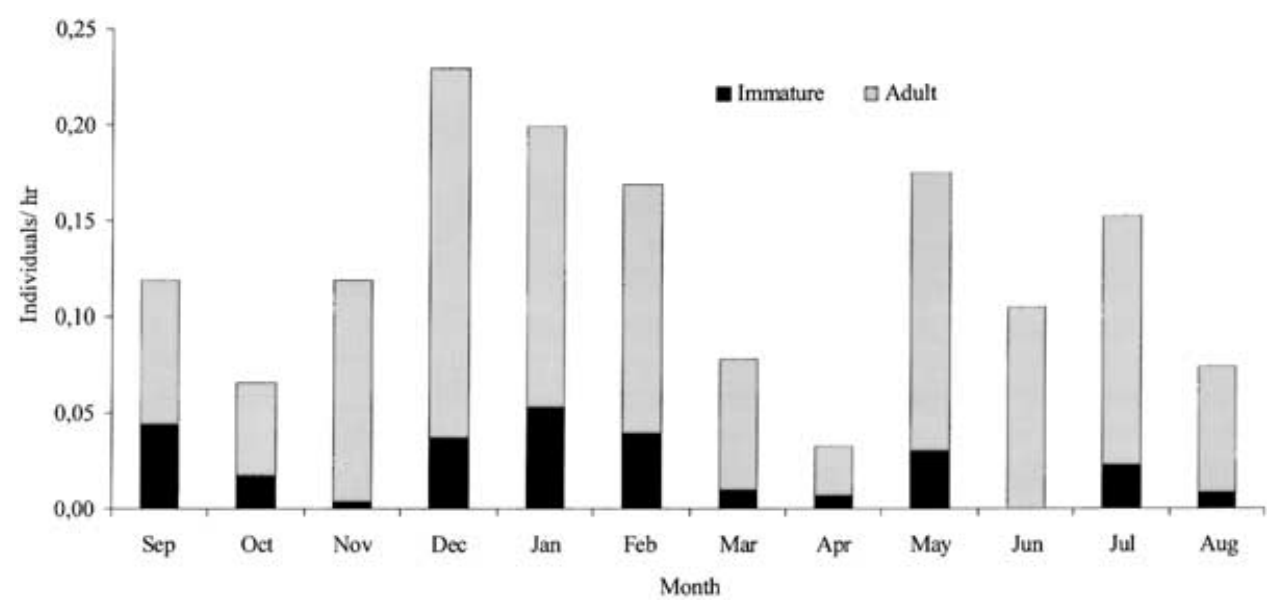

Figure 3. Temporal distribution of observation frequency for different age groups of Bearded Vultures in Crete (1996-1999). 
Table 1. Altitude (in $\mathrm{m} \pm$ S.E.) at which Bearded Vultures were recorded foraging, for different age groups and season in Crete (1996-2001)

\begin{tabular}{llllll}
\hline Season & Adult $(n)$ & Range & Immature $(n)$ & Range & $t$ - test \\
\hline All year & $1,135 \pm 27(278)$ & $200-2,450$ & $1,002 \pm 72(53)$ & $300-2,100$ & ns \\
Winter & $977 \pm 32(134)$ & $200-2,000$ & $746 \pm 72(27)$ & $300-1,800$ & $2,93^{*}$ \\
Summer & $1,291 \pm 38(142)$ & $300-2,450$ & $1,240 \pm 109(26)$ & $300-2,100$ & ns \\
\hline
\end{tabular}

$* P<0.05$

affected more by the age of the individuals than by the month $\left(F_{1,11}=46.36, P<\right.$ $0.05 ; F_{11,11}=1.88, P>0.05$ ).

The average altitude at which birds were sighted was $1,100 \mathrm{~m}$ (range $=200-$ $2,450 \mathrm{~m}$ ) and was significantly higher in summer (mean $1,266 \mathrm{~m}$, range $=300-$ 2,450 $\mathrm{m}, n=129$ ) than in winter (mean $942 \mathrm{~m}$, range $=200-2,000 \mathrm{~m}, n=133 ; z=$ $6.15, P<0.01)$. Adult birds were at significantly higher altitudes than immatures in winter (Table 1). During winter months Bearded Vultures were regularly recorded in the vicinity of their nesting cliffs and this applied also to territorial birds without a mate. In many cases solitary individuals were seen rebuilding their nests or storing food in the nest, but mostly roosted on nearby ledges. In summer, birds frequented the upland pastures of the major massifs (Figure 4). Winter roosts $(n=9)$ were visited by the birds prior to the breeding season in mid autumn to early spring with six being situated in close proximity to nests $(<300 \mathrm{~m})$. Their altitude ranged from $280 \mathrm{~m}$ to $900 \mathrm{~m}$ (mean $554 \mathrm{~m}$ ). Summer roosts $(n=9)$ were in mid altitude areas well above the tree line on rocky outcrops of the alpine zone ranging from $850 \mathrm{~m}$ to 2,000 $\mathrm{m}$ (mean $1,467 \mathrm{~m}$ ). The mean altitude of roosts used all year round was $918 \mathrm{~m}$ (range $=550-1,380 \mathrm{~m}, n=$ 14) with $57 \%$ of them placed near nests. Adult birds were fairly evenly distributed over the mountain regions of the island while the distribution of the immature birds was marginal to the three mountain massifs and included low altitude areas or deserted territories (Figure 5). In addition immature birds often joined and followed groups of other scavengers such as Griffon Vultures Gyps fulvus, which were foragers of the hills and the plains: $32 \%$ of the observations of immature birds were in association with G. fulvus (e.g. soaring in the same thermal or roosting within their colonies).

\section{Discussion}

Depending almost entirely on domestic animals, Bearded Vultures have to follow seasonal movements of livestock, and forage from November to March in middle and low altitude areas, where food availability is higher. Furthermore they are forced to nest on low altitude cliffs in order to achieve optimal foraging when feeding their young. The altitude of nest sites in Crete, according to the existing literature, is the lowest recorded throughout the species' global range (e.g. Spanish Pyrenees, southern Africa, Caucasus, Corsica; Heredia and Heredia 1991, Brown et al. 1988, Abuladze 1998, Fasce et al. 1989).

Nest site availability at higher altitudes should not be regarded as a limiting factor. There were numerous vertical cliffs bearing suitable ledges or small caves where the species was sighted storing food during summer months. In addition, 

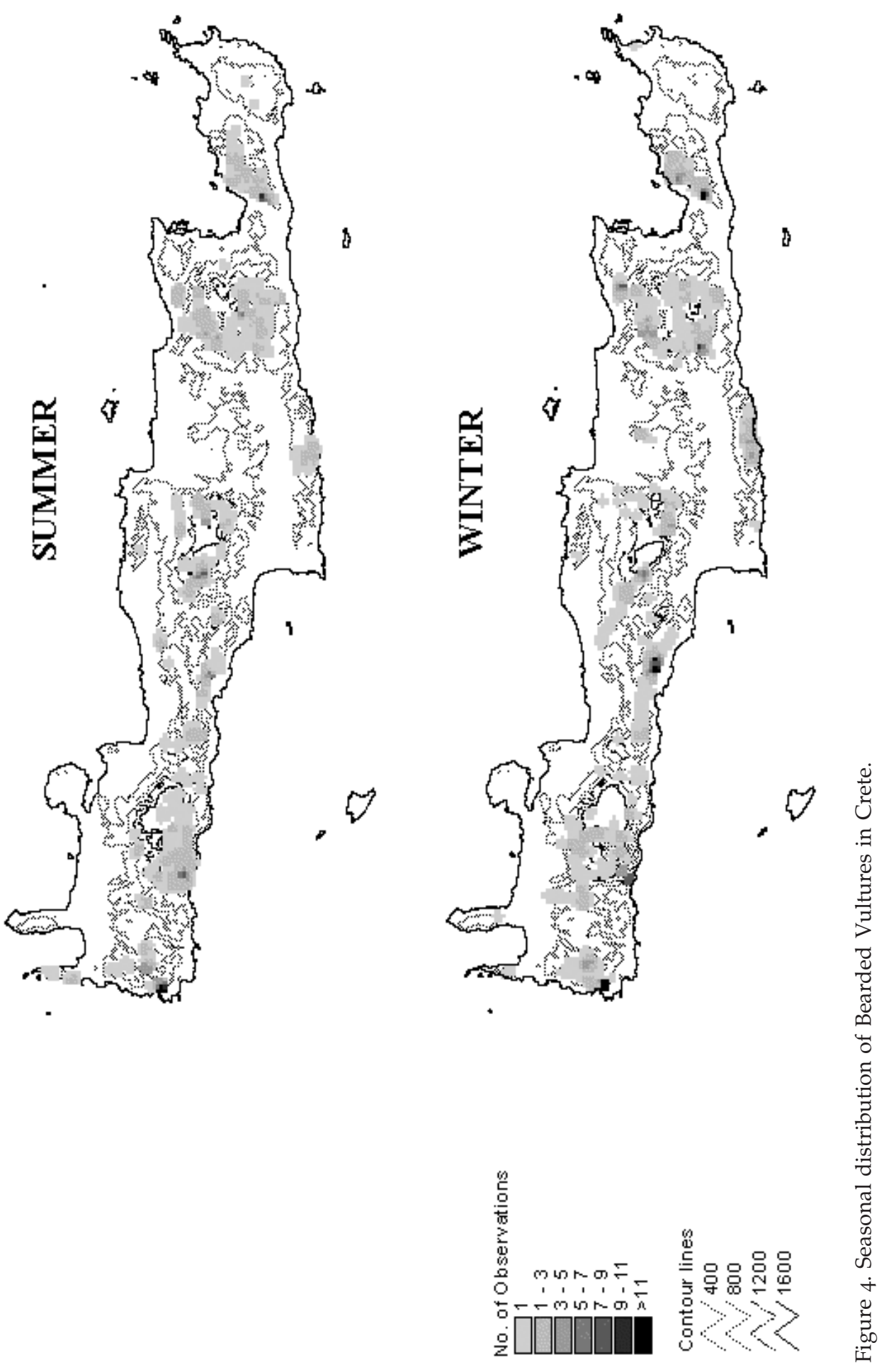

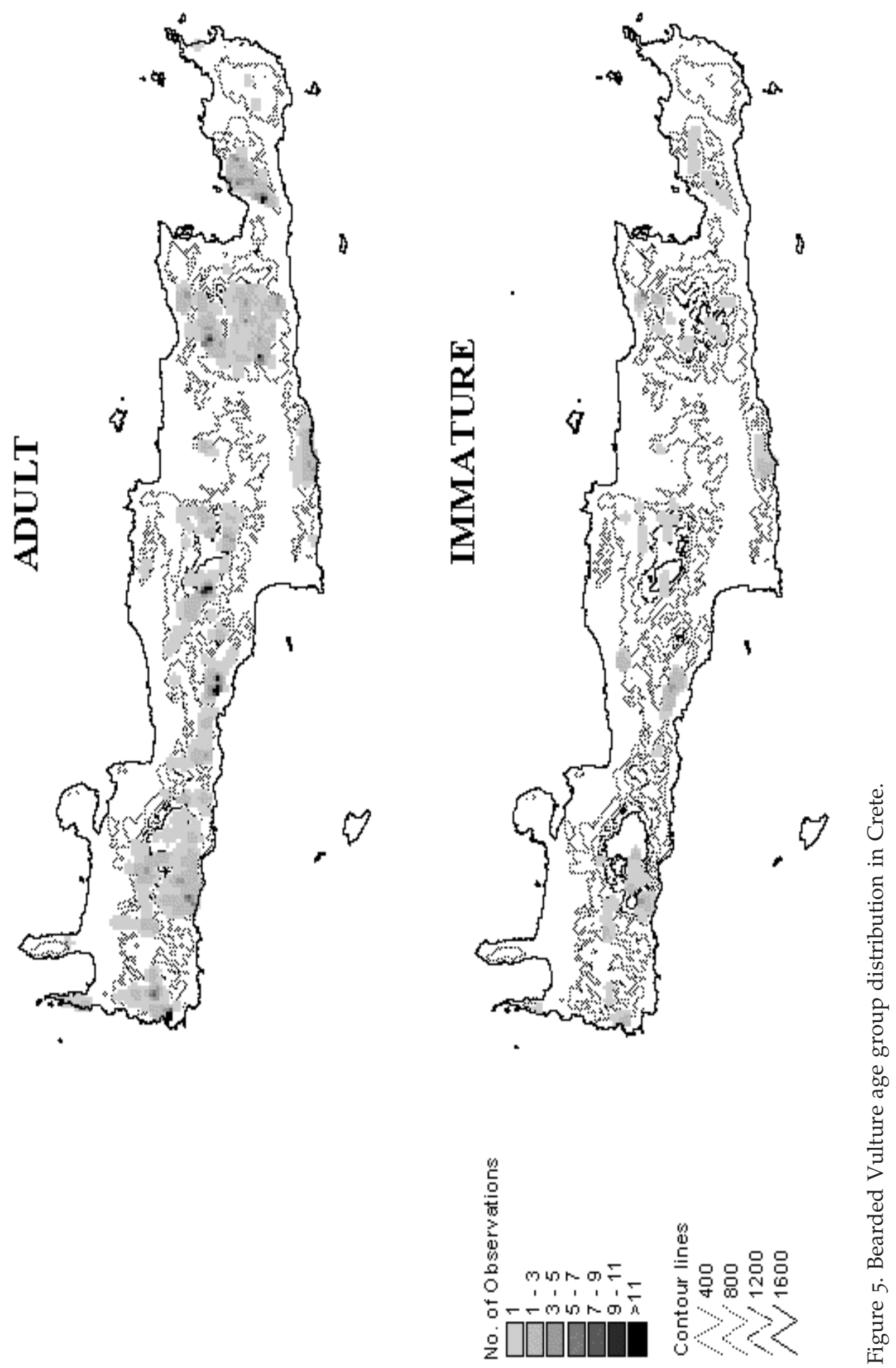
although relevant data are scarce, it seems that breeding performance depends more on the quality of territory in terms of food than nest site availability. During 1996-2001 a pair nesting at $550 \mathrm{~m}$ a.s.l. raised a chick after four years of no breeding activity only when supplied with food (Xirouchakis et al. 2000). In the meantime a pair nesting at $650 \mathrm{~m}$ a.s.l. in the Samaria National Reserve, an area that supports the only wild ungulate population on the island (i.e. Cretan Wildgoat Capra aegagrus cretensis), bred successfully in four years of monitoring.

Differences in distribution pattern and sighting rates between adult and young birds can be attributed to differences in their morphometrics, flight behaviour and survival rates. Immature Bearded Vultures have on average broader wings, a lower aspect ratio and broader tails compared with adults (Hiraldo et al. 1979, Delibes et al. 1984, Brown 1989). This makes them more efficient at using thermals, and thus facilitates the exploitation of a wider spectrum of habitats away from the most mountainous areas preferred by the adults. The low sighting rate of immature birds during summer might also be the product of high winter mortality that has been demonstrated for the species (Hiraldo et al. 1979, Brown 1997).

Bearded Vulture was regarded as ecologically stable and secure in Greece in the 1980 os, as a dweller of remote mountain areas and a breeder of high, inaccessible cliffs (Handrinos 1985). However, it has proved to be quite vulnerable to human- induced mortality such as poisoning and shooting. A high adult mortality rate had probably the greatest impact on its population as in all long-lived raptors (Mertz 1971). In mainland Greece anti-wolf poisoning campaigns are suspected as the major cause of its disappearance, while in Crete direct persecution by man has been the prime cause for its decline (Sakoulis 2001, Xirouchakis et al. 2001). However in Crete, some of the conservation problems seem to be indirectly related to the species' seasonal distribution. Livestock husbandry methods and sanitary conditions (e.g. outdoor abattoirs and illegal dumps) have supported higher biomass figures than natural ecosystems, as in most altered environments throughout the world (Brown 1977, Galushin 1971, Donazar 1992, Mundy et al. 1992, Houston 1996). After 1981 when Greece joined the European Union, stock farmers received significant subsidies under the Common Agricultural Policy. Animal numbers increased dramatically by up to $70 \%$ in some parts of the island and stocking densities on the traditional rangelands reached up to four times the carrying capacity of the natural vegetation (Lyrintzis 1996). Overstocking in combination with fire for grassland improvement has caused degradation of rangelands, soil erosion and desertification (Strid et al. 1995, Menjli and Papanastasis 1995, Hill et al. 1998). Consequently domestic ungulates were supported with supplementary feeding on a daily basis. This has been especially so in winter months during the last decade when most animals have been kept in large enclosures or in pens around villages at 600-900 $\mathrm{m}$ a.s.l., or even lower near the coastline. We have witnessed Bearded Vultures foraging near wintering livestock pens, feeding on carcasses thrown in nearby ravines or collecting wool and skins from lambs that died at birth. The winter foraging distribution of the species and its nest site selection at low altitudes makes it vulnerable to human-induced threats. This is compounded by an extensive network of roads, which provide easy access for people, and the strong philopatric behaviour of adult birds, which insist on using breeding territories with ongoing disturbance. In eight docu- 
mented incidences of human persecution in the 1990s, five birds (three immature and two adult) were shot during late autumn months in places ranging in altitude from $500 \mathrm{~m}$ to $1,100 \mathrm{~m}$ a.s.l. (mean $800 \mathrm{~m}$ ). Unfortunately abandoned territories with high levels of human pressure are attractive to immature birds that prefer using areas with low adult densities.

\section{Acknowledgements}

We would like to thank G. Giannatos, G. Andreou, A. Sakoulis, O. Chilitidis, G. Arnellos, C. Papazoglou, C. Grivas, G. Roussopoulos for assisting in fieldwork. We also thank Dr Chris Brown and an anonymous referee for comments on the manuscript and Steven Roberts for improving the English text. This study has been partially funded by a LIFE project of the European Union (B4-3200/98/ 444).

\section{References}

Abuladze, A. (1998) The Bearded Vulture Gypaetus barbatus in Caucasia. Pp. 177-182 in R. Chancellor, B.-U. Meyburg and J. Ferrero, eds. Holarctic birds of prey. Proceedings of an International Conference. Calamonte, Spain: ADENEX-WWGBP.

Bilstein, K. L. (1978) Behavioural ecology of Red-Tailed Hawks (Buteo jamaicanensis), Rough-legged Hawks (Buteo lagopus), Northern Harriers (Circus cyaneus), American Kestrels (Falco sparverius) and other raptorial birds wintering in south-central Ohio. Ph.D. dissertation, Ohio State University, Columbus, $\mathrm{OH}$.

Brown, L. (1977) The status, population structure, and breeding dates of the African Lammergeier Gypaetus barbatus meridionalis. Raptor Rese. 11(3): 49-58.

Brown, C., Brown, S. and Guy, J. (1988) Some physical parameters of the Bearded Vulture Gypaetus barbatus nest sites in southern Africa. Pp. 45-46 in G. Backhurst, ed. Proceedings of the 6th Pan-African Ornithological Congress: 139-152. Irds. Nairobi, Kenya: The sixth PAOC Organizing Committee.

Brown, C. (1989) Plumage and measurements of the Bearded Vulture in southern Africa. Ostrich 60: 165-171.

Brown, C. and Plug, I. (1990) Food choice and diet of the Bearded Vulture Gypaetus barbatus in southern Africa. S. Afr. J. Zool. 25: 169-177.

Brown, C. (1991) An investigation into the decline of the Bearded Vulture Gypaetus barbatus in southern Africa. Biol. Conserv. 57: 315-337.

Brown, C. (1997) Population dynamics of the Bearded Vulture Gypaetus barbatus in southern Africa. Afr. J. Ecol. 35: 53-63.

Cramp, S. and Simmons, K. E. L., eds. (1980) The Birds of the western Palearctic. Oxford: Oxford University Press.

Delibes, M., Hiraldo, F. and Calderon, J. (1984) Age and geographic variation in the Bearded Vulture Gypaetus barbatus (Linnaeus, 1758). Bonn. zool. Beitr. 35: 71-90.

Donázar, J. A. (1992) Muladares y basureros en la biologia y conservaçion de las aves en España. Ardeola 39 (2): 29-40.

Donázar, J. A., Hiraldo, F. \& Bustamante, J. (1993) Factors influencing nest site selection, breeding density and breeding success in the bearded vulture (Gypaetus barbatus). J. Appl. Ecol. 30: 504-514.

Fasce, P., Fasce, L. and Torre, J. (1989) Census and observations on the biology of the Bearded Vulture Gypaetus barbatus on the island of Corsica. Pp. 335-339 in B.-U. Mey- 
burg and R. D. Chancellor, eds. Raptors in the modern world. Berlin, London and Paris: WWGBP.

Fuller M. R. and Mosher J. A. (1987) Raptor survey techniques. Pp. 37-65 in B. A. G. Pendleton, B. A. Misslap, K. W. Cline and D. M. Bird, eds. Raptor management techniques manual. Washington, DC: National Wildlife Federation.

Forsman, D. (1999) The raptors of Europe and the Middle East: a handbook of field identification. London: I. \& A.D. Poyser.

Galushin, V. (1971) A huge urban population of birds of prey in Delhi, India. Ibis 113: 522.

Handrinos, G. (1985) The status of vultures in Greece. Pp. 103-115 in I. Newton and R. D. Chancellor, eds. Conservation studies in raptors. Salonica: WWGBP (ICBP Techn. Publ. 5).

Heredia, R. and Heredia, B., eds. (1991) El Quebrantahuesos (Gypaetus barbatus) en los Pirineos. Caracteristicas ecológicas y biología de la conservación. Madrid: ICONA.

Hill J., Hostert P., Tsiourlis G., Kasapidis P., Udelhoven T. and Diemer C. (1998) Monitoring 20 years of increased grazing impact on the Greek island of Crete with earth observation satellites. J. Arid Envir. 39: 165-178.

Hiraldo, F., Delibes, M. and Calderon, J. (1979) El Quebrantahuesos Gypaetus barbatus. Madrid: ICONA (Monografias 22).

Houston, D. C. (1996) The effect of altered environments on vultures. Pp. 327-336 in B. D. Bird, D. E. Varland and J. J. Negro, eds. Raptors in human landscapes. London: Academic Press.

Katsavelis, K. Bizaki, A., Souranakis, E. and Raptskis, I. (1993) Epizootiological Study of Crete. Geotechnical chamber of Geece. Regional department of Crete. (In Greek.)

Lyrintzis, G. (1996) Human impact trend in Crete: the case of Psiloritis Mountain. Envir. Conserv. 23 (2): 140-148.

Menjli, M. and Papanastasis, V. (1995) Impact of pastoralism on the desertification of Psiloritis Mountain in Crete, Greece. Sylvopastoral Systems, Cahiers Options Mediterranéennes 12: 117-120. Zaragosa, Spain. CIHEAM.

Mertz, D. B. (1971) The mathematical demography of the California Condor population. Amer. Naturalist 105: 437-453.

Mundy, P. J., D. Butchart, J. Ledger and Piper, S. (1992) The Vultures of Africa. Randburg, South Africa: Acorn Books and Russel Friedman Books.

National Statistical Service (1991) Results of the General Inventory of Agriculture and Pastoralism in Greece. (In Greek.)

Penna, P. (1977) The climate of Crete. Unpubl. Ph.D. thesis. Aristotelian University, Salonica. (In Greek.)

Sakoulis, A. (2001) The decline of Bearded Vulture in central Greece and anti-wolf campaign. Fourth Eurasian Conference of the Raptor Research Foundation. Seville, Spain, 23-26 September 2001. Abstracts: 162-163.

Strid, A., Damanakis, M., Bergmeier, E. and Matthas, S. (1995) Desertification in the White Mountains of Crete. A botanical study with special reference to the effects of grazing and wildfires. Final report Contract EV 5 V-CT91-0031, European Community.

Suetens, W. and Van Groenedael, P. (1973) Notes on the ecology and ethology of the Lammergeier, Gypaetus barbatus aureus (Hablizl). Gerfaut 62: 203-214.

Thibault, J. C., Vigne, J. D. and Torre, J. (1992) The diet of young Lammergeiers Gypaetus barbatus in Corsica: its dependence on extensive grazing. Ibis 135: 42-48.

Tucker, G. M. and Heath, F. A. (1994) Birds in Europe: their conservation status. Cambridge, U.K.: Birdlife International (Conserv. Series 3).

Xirouchakis, S., Sakoulis, A. and Andreou, G. (2000) Bearded vulture population in Crete in 1998-2000: status and breeding performance. P. 74 in H. Frey, G. Schaden and M. 
Bijleveld, eds, (2001) Bearded vulture annual report 2000. Wassenaar: Foundation of the Conservation of the Bearded Vulture.

Xirouchakis, S., Sakoulis, A. and Andreou, G. (2001) The decline of the Bearded Vulture Gypaetus barbatus in Greece. Ardeola 48(2): 183-190.

Zar, J. (1984) Biostatistical analysis. Englewood Cliffs, NJ: Prentice-Hall.

STAVROS XIROUCHAKIS and MANOLIS NIKOLAKAKIS

Natural History Museum of Crete, University of Crete, P.O. Box, 2208, Heraklion 71409, Crete, Greece.

Received 30 October 2001; revision accepted 22 April 2002 